\title{
Recruitment of young-of-the-year bluefish Pomatomus saltatrix to the New York Bight: variation in abundance and growth of spring- and summer-spawned cohorts
}

\author{
Richard S. McBride*, David O. Conover \\ Marine Sciences Research Center, State University of New York, Stony Brook, New York 11794-5000, USA
}

\begin{abstract}
The bluefish Pomatomus saltatrix spawns offshore in continental shelf waters and juveniles migrate to near-shore or estuarine waters during their first growing season. In estuaries of the New York Bight during 1987 and 1988, young-of-the-year bluefish appeared in 2 discrete size groups. Otolith analyses confirmed that the 2 groups originated from distinct spring and summer spawning periods. The spring-spawned cohort first recruited to estuaries in early to mid-June, whereas the summer-spawned cohort first recruited in middle to late August. In contrast with previous years when only spring-spawned fish were abundant, the overall abundance of spring vs summer cohorts was similar There were, however, significant differences in abundance among bays that depended on cohort. Much of this variation in abundance is probably caused by variation in advective transport of larvae from spawning grounds to estuaries. Growth patterns differed substantially between the 2 cohorts. Spring-spawned bluefish grew slower than summer-spawned bluefish during the pre-recruitment oceanic phase of the early life history, perhaps because their northward transport causes them to encounter lower temperatures during the larval period. Both cohorts grow rapidly after estuarine recruitment, but spring-spawned bluefish are much larger than summer-spawned bluefish at the onset of fall migration. Overall year-class strength of bluefish along the US mid-Atlantic coast is a function of the combined recruitment success of the spring and summer cohorts.
\end{abstract}

\section{INTRODUCTION}

The bluefish Pomatomus saltatrix (Linnaeus) is among the relatively few marine fishes having a worldwide distribution (Briggs 1960). Fisheries for bluefish are found in the western North Atlantic (Bigelow \& Schroeder 1953, US Dept of Commerce 1988), southern Africa (van der Elst 1976), western Australia (Lenanton \& Potter 1987), and other areas, but in none of these regions do we have a detailed understanding of how spatial and temporal variation in spawning and recruitment affect the population dynamics of bluefish.

Previous studies in the western North Atlantic suggest that the spawning and recruitment tactics of bluefish are unusual. Rather than having one major spawning season, as do most other temperate marine fishes

\footnotetext{
- Present address: Marine Field Station, Institute of Marine and Coastal Sciences, Rutgers University, Box 278, Tuckerton, New Jersey 08087, USA
}

(Bye 1990), bluefish appear to have multiple but distinct spawning seasons that contribute recruits to the same geographic region (Kendall \& Walford 1979). Bluefish spawn on, or near the edge of, the continental shelf of eastern North America during at least 2 major periods: (1) in the South Atlantic Bight (i.e. the region from southern Florida to Cape Hatteras) from March to May (referred to here as the spring spawning season), and (2) in the Middle Atlantic Bight (i.e. the region from Cape Hatteras to Cape Cod) from June to August (the summer spawning season). Less intense spawning may occur additionally in the South Atlantic Bight during September to November (Kendall \& Walford 1979, Collins \& Stender 1987). Larval development occurs near the surface and young bluefish are dispersed by prevailing currents, and perhaps active migration, to estuarine nurseries (Norcross et al. 1974, Kendall \& Walford 1979, Powles 1981).

The relative contribution of these various spawning events to recruitment along the Atlantic coast of North 
America is not clear. Nyman \& Conover (1988) demonstrated that young-of-the-year (YOY) bluefish from the spring spawning event are transported northward to the Middle Atlantic Bight. They examined otoliths of newly recruited YOY fish collected from Long Island, New York, and determined that nearly all had been spawned in the spring. These spring-spawned fish are apparently advected northward in currents associated with the Gulf Stream (Kendall \& Walford 1979, Shima 1990). Summer-spawned fish are also believed to recruit to estuaries of the Middle Atlantic Bight (Kendall \& Walford 1979). Summer-spawned YOY bluefish, however, were rarely captured from Long Island by Nyman \& Conover (1988). This is surprising because spawning is known to occur just offshore of Long Island during July (Sherman et al. 1984, Chiarella \& Conover 1990).

Possible explanations for low recruitment of summer-spawned YOY to Long Island are the following First, summer-spawned bluefish may simply recruit elsewhere. Because surface currents in the New York Bight during summer are principally toward the southwest (Bumpus 1969, Kendall \& Walford 1979, Sherman et al. 1984), bluefish spawned in the upper reaches of the New York Bight may be generally transported toward New Jersey (see Fig. 1). Accordingly, Vouglitois (1983) found that in some years bluefish from Barnegat Bay, New Jersey, had a bimodal length-frequency pattern in late summer. Moreover, the only summer-spawned fish encoun- tered by Nyman \& Conover (1988) were captured to the west of Long Island in the lower Hudson River. Second, summer-spawned bluefish may have poor survival and contribute little to recruitment. Supporting this view is the observation that few adult bluefish from the New York Bight appear to be products of the summer spawning season (Chiarella \& Conover 1990). Finally, summer-spawned bluefish may not grow fast enough to reach the size threshold required for inshore migration prior to the onset of winter (Kendall \& Walford 1979).

Here we evaluate the above alternatives and compare the relative contribution of the spring vs summer spawning seasons to recruitment of YOY bluefish in the New York Bight.

\section{MATERIALS AND METHODS}

Field sampling. Sampling stations were concentrated in 3 different areas: Great South Bay in New York and embayments near the towns of Tuckerton and Cape May, New Jersey (Fig. 1). Collections were made with a $30 \times 2 \mathrm{~m}$ beach seine $6 \mathrm{~mm}$ mesh in the wings, $3 \mathrm{~mm}$ mesh bag) from May to October in 1987 and 1988. In Great South Bay, sampling frequency was at least every $6 \mathrm{~d}$ until bluefish first appeared and every 2 to 3 wk thereafter (see Fig. 2). In New Jersey, sampling frequency was every 2 to $3 \mathrm{wk}$. Each of the 3 areas contained 4 stations [see McBride (1989) for

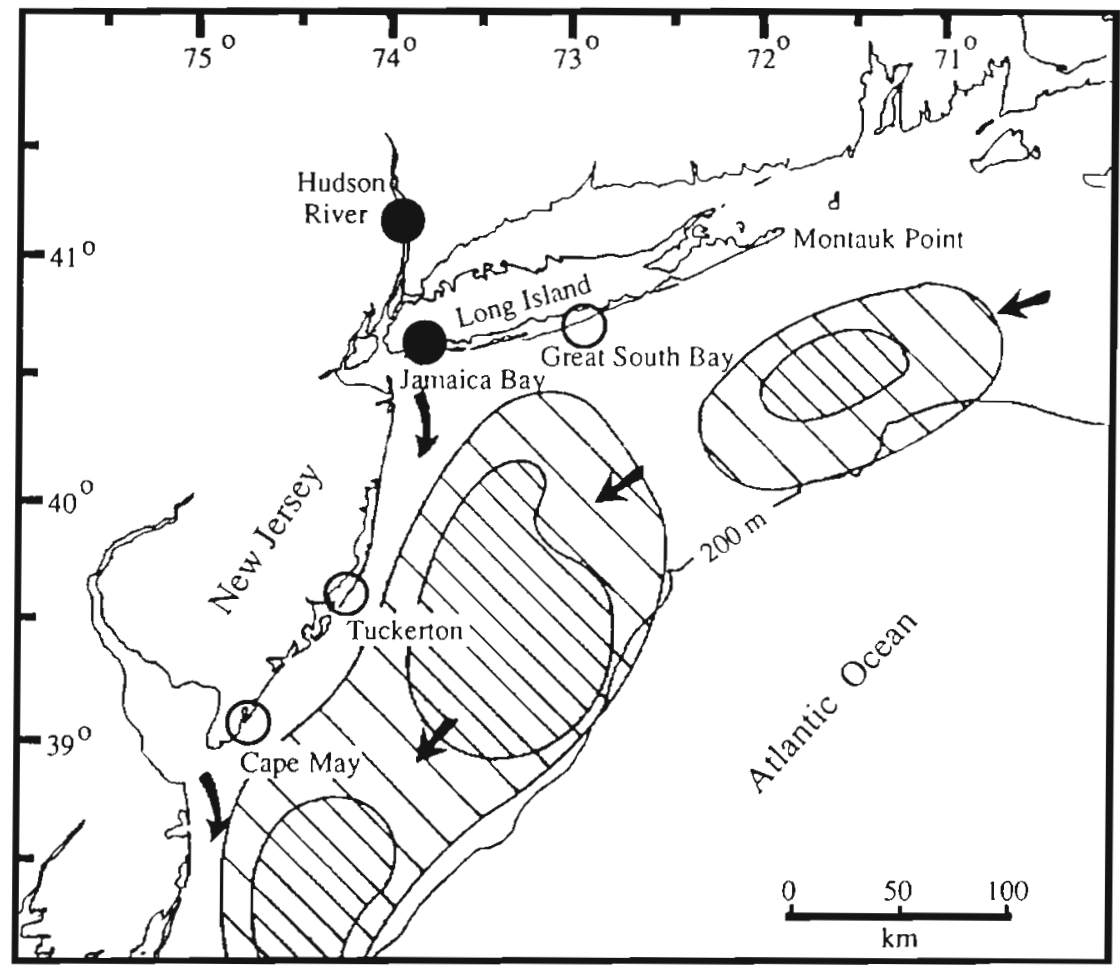

Fig. 1 Estuaries sampled within the New York Bight. Those marked with an open circle (Great South Bay, Tuckerton, and Cape Mayl were sampled by us with a $30 \mathrm{~m}$ seine. Those marked with a filled circle (Hudson River and Jamaica Bay) were sampled by the New York Dept of Environmental Conservation with a $60 \mathrm{~m}$ seine. Also depicted are the density of bluefish larvae over the contmental shelf (single hatched lines $=1$ to $10 \mathrm{~m}^{-2} ;$ double hatched lines $=10$ to $100 \mathrm{~m}^{-2}$ ) based on data for summer 1980 (from Sherman et al. 1984) and the direction of surface water flow in the summer (arrows) based on Bumpus (1969) 
specific locations] and 3 hauls were completed at each station. Successive hauls began at an adjacent stretch of beach after the preceding catch had been processed. Sampling of each area lasted $1 \mathrm{~d}$. The net was set from shore by wading to a depth of about $1.0 \mathrm{~m}$ with one end of the net, and sweeping the other end of the net through as wide an arc as possible. Relative abundance [= catch per unit effort (CPUE)] of bluefish was calculated as number of fish caught per seine haul.

Additional collections of YOY bluefish and CPUE data from Jamaica Bay and the Hudson River (Fig. 1) during 1987 and 1988 were provided to us by the New York Department of Environmental Conservation (NYDEC). They typically sampled 6 to 8 stations in Jamaica Bay and 25 stations in the Hudson River. Sampling in both areas required $2 \mathrm{~d}$ to complete. Sample frequency was every 2 to $3 \mathrm{wk}$ from May to November in Jamaica Bay and from July to November in the Hudson River. They used a $60 \times 3 \mathrm{~m}$ beach seine $(12 \mathrm{~mm}$ mesh wings: $6 \mathrm{~mm}$ mesh bag) set by boat in as wide an arc as possible (Young et al. 1988). The NY-DEC also contributed additional specimens of bluefish from monthly (July to September) collections during 1988 in Great South Bay.

Otolith analyses. Bluefish were chilled on ice in the field and frozen upon return to the lab. Fork lengths of thawed fish were measured to the nearest millimeter. Otoliths were removed from randomly selected fish within distinct length modes.

YOY bluefish were aged by counting daily rings of sagittal otoliths. Validation of daily ring deposition was reported by Nyman \& Conover (1988) and our preparation of otoliths followed their method. Otoliths were coded and randomly sorted before counting. Ring counts were performed by viewing a video image produced by a compound microscope fitted with a video camera at magnifications of 250 or $400 \times$. Age in days was estimated as the mean of 3 independent counts of sagittal increments. An average count was accepted if the range of the 3 counts was $<10 \%$ of the mean. If the counts had a greater range (which occurred $18 \%$ of the time), then a fourth count was made and the outlier discarded. If the fourth count was unsuccessful in reducing the range to $<10 \%$ of the mean, then all counts were discarded. This occurred in 9 of 182 otoliths read. No correction was made for the lag between spawning and date of first ring deposition but this difference is only about 2 to $4 \mathrm{~d}$ (Nyman \& Conover 1988).

Otolith analyses were concentrated primarily on fish captured in 1987. Additional specimens from 1988 were examined to establish their consistency with findings from 1987. Mean ages are given with \pm 1 standard deviation.

Growth rate. Once fish were assigned to each cohort, growth rates were calculated separately for spring- and summer-spawned cohorts over 2 periods of the early life history: the oceanic or pre-recruitment phase, and the estuarine or post-recruitment phase. For each cohort in a sample area, pre-recruitment growth was estimated from the age and size of fish at first recruitment (i.e. first date of capture). Growth rate was calculated as [fork length (FL, mm) - 2]/[age (d)]. This equation corrects for size attained $(2 \mathrm{~mm}$ ) prior to first ring deposition (Nyman \& Conover 1988). Estuarine or post-recruitment growth rates were estimated from least squares linear regressions of fork length on date of capture.

Statistical analyses. Relative abundance between years (1987 and 1988), cohorts (spring- and summerspawned), and bays (Great South Bay, Tuckerton, and Cape May) were analyzed using a 3-way, fixed-effects analysis of variance. NY-DEC data were excluded from this analysis because of different sampling gear. Previous studies in Great South Bay showed that CPUE of YOY bluefish is constant for about the first month after initial recruitment to the shore zone, but then declines [see Fig 2 in Nyman \& Conover (1988)] probably as a result of gear avoidance or movement to deeper water as the fish grow larger. For this reason, we used CPUE values for the 1 mo interval following each cohort's date of first recruitment. This 1 mo interval represents the period when each cohort is at maximum abundance in the shore zone. The analysis was conducted using the General Linear Model (GLM) procedure provided in SAS (1988). CPUE data were normalized before formal analysis by use of a rank transformation (Conover \& Iman 1976).

Oceanic growth rates were compared among cohorts by Student's t-tests. Length-age relationships were compared among cohorts within years by ANCOVA using fish spanning a range of ages (50 to $100 \mathrm{~d}$ ) common to both cohorts. Length and age were log transformed to homogenize the variance about regression. Within each cohort, estuarine growth rates were compared to oceanic growth rates by Student's t-tests. Significance level in all cases was 0.05

\section{RESULTS}

\section{Timing of and size at recruitment to estuaries}

In all sampling areas, YOY bluefish were first collected in early to mid-June of both years (Fig. 2). Bluefish collected in June from all sample sites were 45 to $65 \mathrm{~mm}$ FL (Fig. 3). Because the abundances of bluefish in 1987 and 1988 were relatively low, lengthfrequency distributions were pooled by month and region (i.e. Long Island, Hudson River, New Jersey) to 
increase sample size. YOY bluefish captured in June showed a unimodal length-frequency distribution which persisted as the fish increased in size during July.

A second influx of small bluefish ( $<75 \mathrm{~mm}$ ) occurred during August or early September in all study areas in both years. These smaller bluefish were clearly identified as a distinct mode in length-frequency distributions (Fig. 3). The timing of this influx of smaller fish appeared to differ somewhat between years. In 1987 , small YOY bluefish were first captured in mid-August in all sampling areas except Great South Bay, where they first appeared in early September (Fig. 2). In 1988 the recruitment of a second cohort of bluefish did not occur until late August or September.

\section{Age and back-calculated spawning periods}

Individuals recruiting in mid-June were determined by otolith ageing to be about 2 mo old (Table 1). The mean age at recruitment in mid-June 1987 was $68.5 \pm$
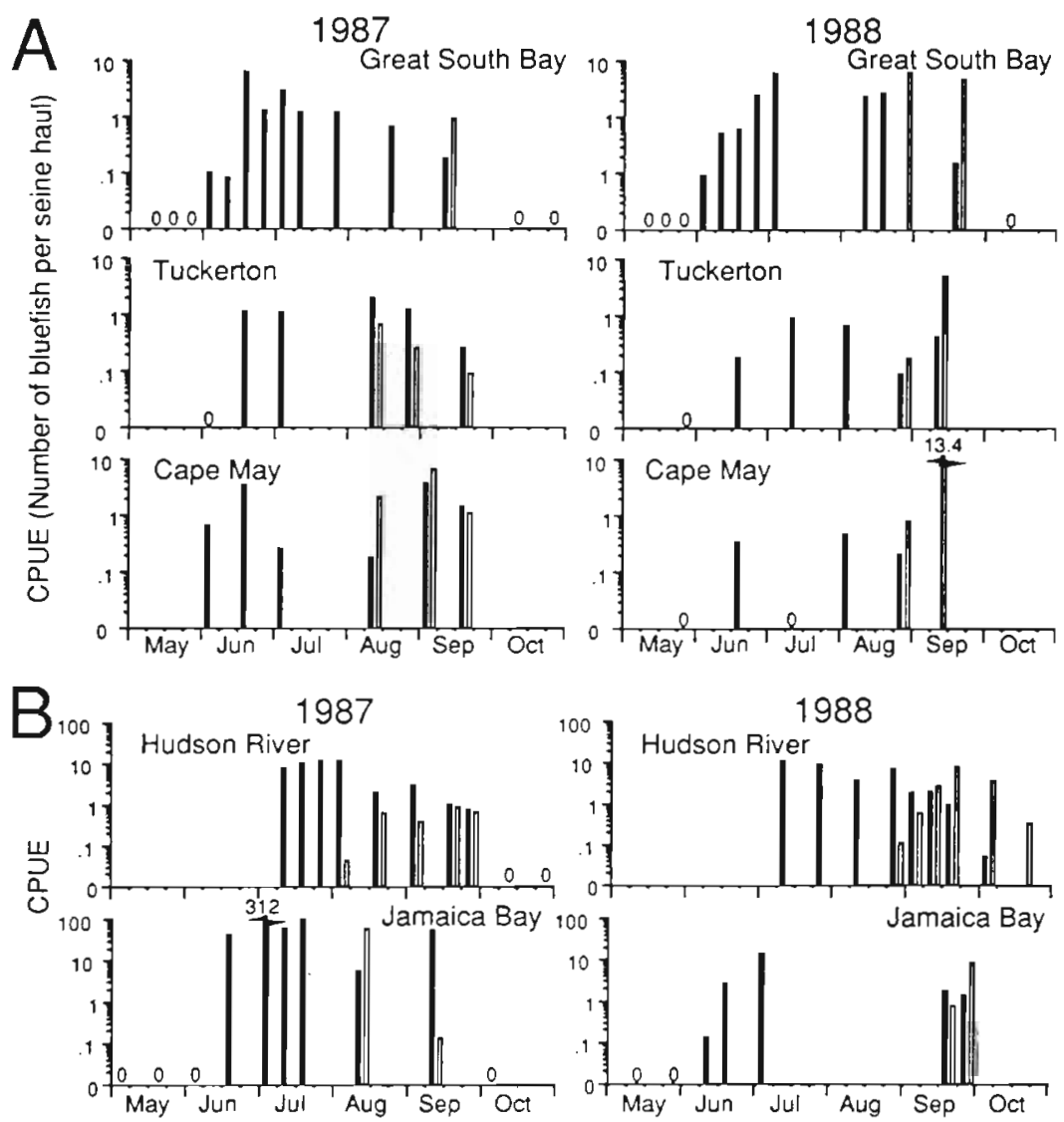

Fig. 2. Pomatomus saltatrix. Relative abundance (CPUE) of young-of-theyear spring-spawned (filled bars) and summer-spawned (open bars) bluefish, plotted on a logarithmic scale. CPUE was measured with a $30 \mathrm{~m}$ seine in $(A)$ and a $60 \mathrm{~m}$ seine in (B). Bluefish were assigned to each cohort based on length-frequency distributions (e.g. fish $<75 \mathrm{~mm}$ captured in mid-August or $<150 \mathrm{~mm}$ in mid-September were plotted as summer-spawned fish). Zeros indicate sampling dates where no bluefish of either cohort were captured

Table 1. Pomatomus saltatrix. Age (d) \pm 1 SD for bluefısh durng 1987 only (sample sizes in parentheses). Fish were presumed to belong to 1 cohurt ur the other, prior to ageing, based on the length mode from which they were selected and from their capture date. Dates of spawning back-calculated from these data confırm our presumptions (see Fig. 4). 'New York' comprises bluefish from Great South Bay and Jamaica Bay, while 'New Jersey' includes bluefish from Tuckerton and Cape May

\begin{tabular}{|lcccc|}
\hline Sample date & $\begin{array}{c}\text { Presumptive spring-spawned fish } \\
\text { New York }\end{array}$ & New Jersey & Presumptive summer-spawned fish \\
New York & New Jersey \\
\hline 2-8 Jun & $50 \pm 0.0(2)$ & $59.0 \pm 6.8(4)$ & - & - \\
15-18 Jun & $65.7 \pm 6.7(19)$ & $72.9 \pm 10.3(12)$ & - & - \\
1-2 Jul & - & $81.4 \pm 7.2(6)$ & - & - \\
14 Jul & $91.1 \pm 6.2(9)$ & $1.17 .5 \pm 21.6(9)$ & $35.7 \pm 3.9(6)$ & $42.4 \pm 7.5(11)$ \\
12-13 Aug & $108.8 \pm 5.6(6)$ & $139.2 \pm 19.6(3)$ & $58.0 \pm 5.4(5)$ & - \\
8-10 Sep & $135.8 \pm 13.0(3)$ & - & $74.9 \pm 10.9(9)$ \\
18 Sep & - & & & - \\
\end{tabular}



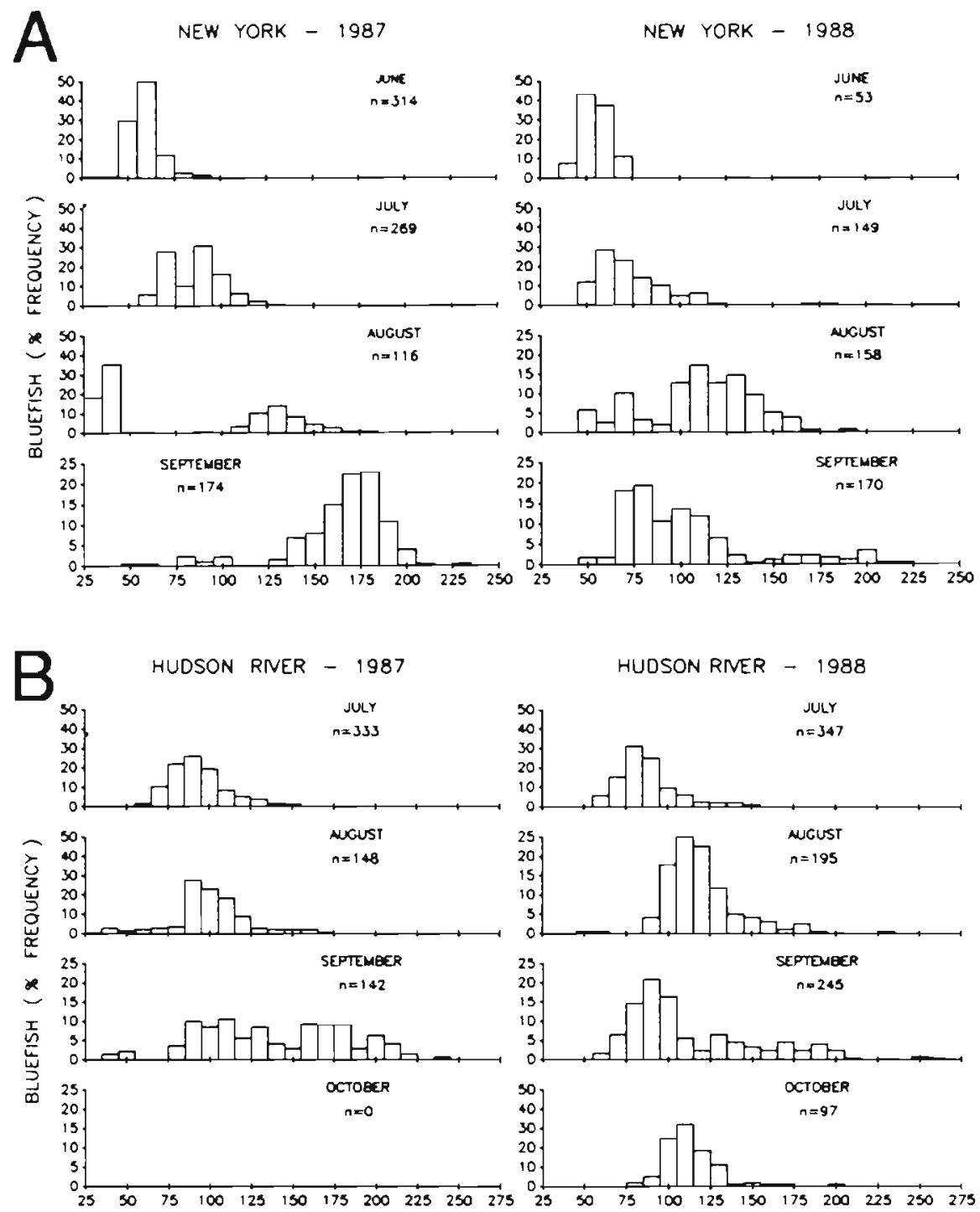

C
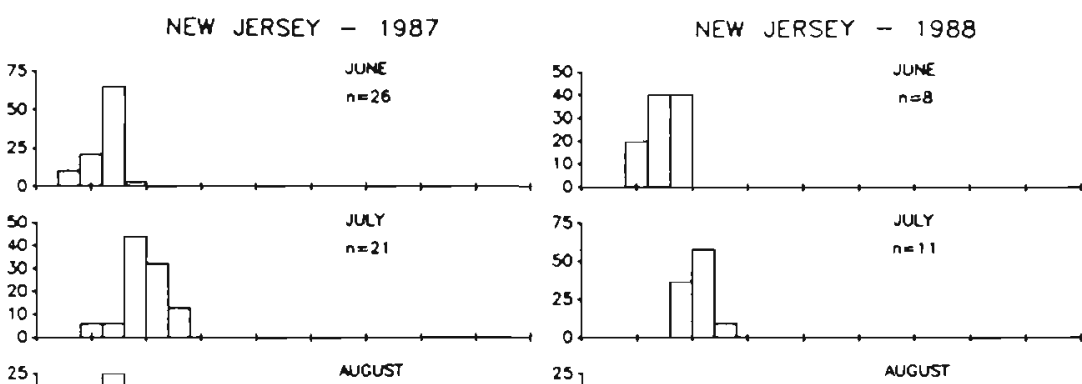

Fig. 3. Pomatomus saltatrix. Length-frequency histograms for young-of-theyear bluefish from (A) Great South Bay and Jamaica Bay, (B) the Hudson River, and (C) Tuckerton and Cape May
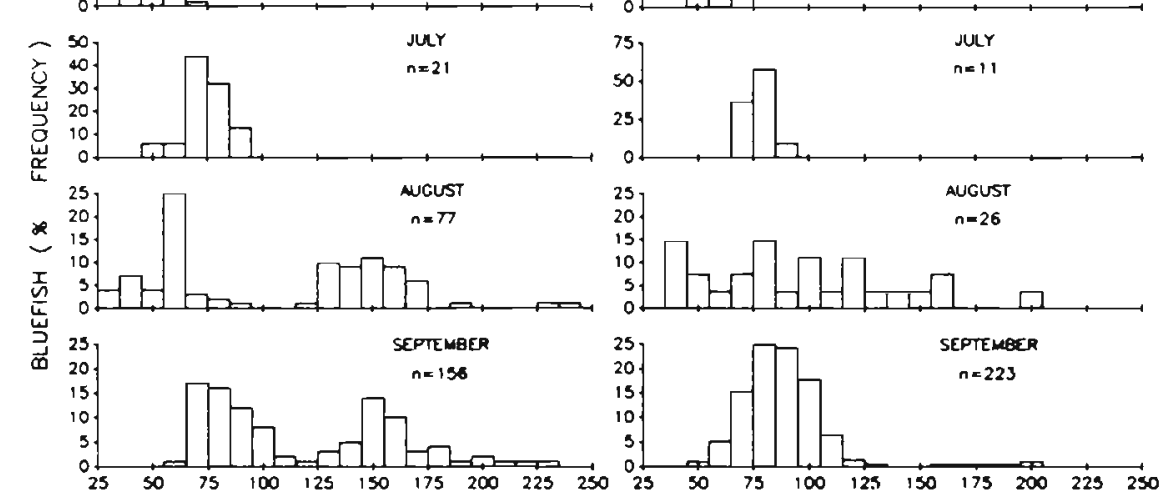

FORK LENGTH ( $\mathrm{mm}$ ) 
$8.9 \mathrm{~d}$ ( $\mathrm{NY}$ and NJ samples combined, $\mathrm{n}=31$; Table 1 ). Results for 1988 were similar. Although fewer Junecollected fish were examined in 1988, mean age at first recruitment for individuals captured on 13 June was $66.0 \pm 6.6 \mathrm{~d}(\mathrm{n}=6)$. A 66 to $68 \mathrm{~d}$ old fish captured in mid-June would have been spawned in early April.

Fish from the smaller size mode captured in midAugust 1987 were 40.0 $\pm 7.1 \mathrm{~d}$ old (NY and NJ samples combined, $\mathrm{n}=17$; Table 1 ). Their birthdates would therefore have been in early July. In 1987, summerspawned fish recruited to the shore zone at an earlier age (spring fish $=68 \mathrm{~d}$, summer fish $=40 \mathrm{~d} ; t=11.4$, $\mathrm{p}<0.001$ ) and smaller size (spring fish $\bar{x}=60 \mathrm{~mm} \mathrm{FL,}$ summer fish $\bar{x}=46 \mathrm{~mm} \mathrm{FL} ; t=7.55, \mathrm{p}<0.001$ ) than did the spring-spawned fish. In 1988, however, springand summer-spawned bluefish recruited at about the same age (spring fish $=66 \mathrm{~d}$, summer fish $=60 \mathrm{~d}$; $t=1.19, \mathrm{p}>0.05$ ) and size at first recruitment was greater in summer-spawned fish (spring fish $\bar{x}=$ $49 \mathrm{~mm} \mathrm{FL}$, summer fish $\bar{x}=60 \mathrm{~mm} \mathrm{FL} ;=3.65, \mathrm{p}$ $<0.01$ ).

Otolith analyses combined with length-frequency plots distinguished spring- and summer-spawned bluefish throughout the growing season. Fish from the

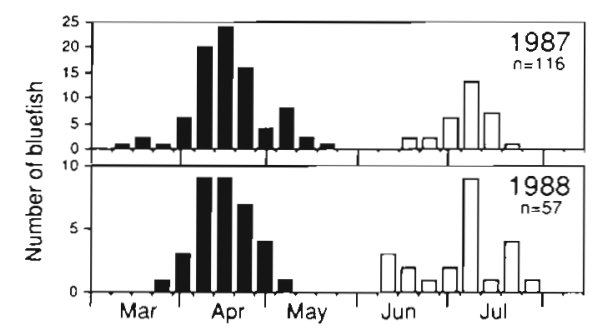

Fig. 4. Pomatomus saltatrix. Back-calculated birthdate distributions from all otolith-aged bluefish captured in the New York Bight. Class interval is $7 \mathrm{~d}$
2 size modes continued to have corresponding differences in birthdate throughout September (Table 1). Fish from the larger size mode collected in early to midSeptember, for example, were about 135 to $140 \mathrm{~d}$ old, corresponding to an April birthdate. Fish from the smaller size mode collected mid-September were about 60 to $75 \mathrm{~d}$ old, indicating a mid-July birthdate.

Birthdates of all fish aged in each year were pooled and the resulting age distributions demonstrated the distinctness of the 2 spawning periods (Fig. 4). The average spring-spawn date during 1987 was 14 April $\pm 12.9 \mathrm{~d}$ ( $\mathrm{n}=85 ;$ range $=8 \mathrm{March}$ to $21 \mathrm{May}$ ). The mean summer-spawn date in 1987 was 7 July $\pm 8.4 \mathrm{~d}$ ( $\mathrm{n}=31 ;$ range $=12$ June to 19 July). Results for 1988 were similar. The mean spring-spawn date in 1988 was 13 April $\pm 9.5 \mathrm{~d}(\mathrm{n}=34$; range $=25$ March to $5 \mathrm{May}$ ). The mean date of summer spawning in 1988 was 5 July $\pm 14.2 \mathrm{~d}(\mathrm{n}=23$; range $=7$ June to 28 July $)$.

\section{Relative abundance of cohorts}

CPUEs of spring- and summer-spawned bluefish, averaged across bays and years, did not differ significantly (Table 2). There were, however, significant Bay (main effect) and Cohort $\times$ Bay interaction effects, indicating that abundance of YOY bluefish in the 3 bays depended on cohort. Spring-spawned bluefish, for example, were most abundant in Great South Bay, whereas summer-spawned bluefish were most abundant at Cape May. The significant Year $\times$ Cohort interaction term indicates that CPUE also depended on cohorts and years. Specifically, summer-spawned fish appeared to have been generally more abundant in 1988 (CPUE $=5.2$ ) than they were in 1987 (CPUE $=$ 1.2), whereas there was little difference among years in CPUE of spring-spawned fish (1987: $1.7 ; 1988: 1.1)$.

Table 2. Pomatomus saltatrix. (A) Arithmetic mean CPUE of young-of-the-year bluefish collected with a $30 \mathrm{~m}$ seine, and averaged over a 1 mo period following initial recruitment. (B) Results of ANOVA of rank transformed CPUE data

\begin{tabular}{|c|c|c|c|c|c|c|c|}
\hline \multirow[t]{2}{*}{ (A) Cohorts } & \multicolumn{2}{|c|}{ Great South Bay } & \multicolumn{2}{|c|}{ Tuckerton } & \multicolumn{3}{|c|}{ Cape May } \\
\hline & 1987 & 1988 & 1987 & 1988 & & 1987 & 1988 \\
\hline Spring-spawned & 3.2 & 2.6 & 1.1 & 0.5 & & 0.9 & 0.2 \\
\hline Summer-spawned & 0.4 & 6.3 & 0.3 & 2.4 & & 3.0 & 7.0 \\
\hline (B) Source of variation & $\mathrm{df}$ & Type III SS & & & $F_{s}$ & & $\mathrm{p}$ \\
\hline Year & 1 & 308.88 & & & 0.38 & & 0.541 \\
\hline Cohort & 1 & 20.54 & & & 0.03 & & 0.875 \\
\hline Bay & 2 & 6099.72 & & & 3.72 & & 0.028 \\
\hline Year $\times$ Cohort & 1 & 7419.62 & & & 9.06 & & 0.003 \\
\hline Cohort $\times$ Bay & 2 & 5502.95 & & & 3.36 & & 0.039 \\
\hline Year × Bay & 2 & 4008.90 & & & 2.45 & & 0.092 \\
\hline Year $\times$ Cohort $\times$ Bay & 2 & 1409.33 & & & 0.86 & & 0.426 \\
\hline Total & 99 & 81062.62 & & & & & \\
\hline
\end{tabular}




\section{Growth rates}

Summer-spawned bluefish grew significantly faster (0.91 to $1.2 \mathrm{~mm} \mathrm{~d}^{-1}$ ) than did spring-spawned bluefish (0.71 to $\left.0.85 \mathrm{~mm} \mathrm{~d}^{-1}\right)$ during the pre-recruitment, oceanic phase of the early life history (Student's $t$-test; Table 3). These differences were observed in both years and for fish from both New York and New Jersey.

The differences in pre-recruitment growth between cohorts was further reflected by marked differences in the relationship between size and age for fish collected in estuaries throughout the summer (Fig. 5). In 1987 , summer-spawned fish were significantly larger than spring-spawned fish of a common age [ANCOVA, $\mathrm{p}($ slope $)=0.86, \mathrm{p}($ intercept $)<0.001]$ with virtually no overlap in size at age up to $100 \mathrm{~d}$. In 1988, summerspawned fish again appeared to be larger than springspawned fish at a given age (Fig. 5), but because both the slope and intercept differed significantly [ANCOVA, $p($ slope $)=0.02, p($ intercept $)=0.01])$, we can conclude only that there was a difference in the size-age relationship of the 2 cohorts.

Increase in mean length of spring-spawned YOY bluefish was essentially linear during the 4 mo they occupied inshore waters (Fig. 6). Estuarine growth rates of spring-spawned fish were rapid, ranging from 1.17 to $1.35 \mathrm{~mm} \mathrm{~d}^{-1}$ (Table 4), and were generally higher than our estimates of oceanic growth rates $(t=7.74, \mathrm{p}<0.001)$. The mean length of summerspawned bluefish also appeared to increase linearly after recruitment to estuaries (Fig. 6). Mean estuarine growth rates for summer-spawned bluefish were variable among years and sites, ranging from 0.57 to $1.47 \mathrm{~mm} \mathrm{~d}^{-1}$ (Table 4), and did not differ significantly from oceanic growth rates of summer-spawned fish ( $t=$ $0.19, p>0.5)$. This high variability may be largely an artifact of the short time period (and therefore few

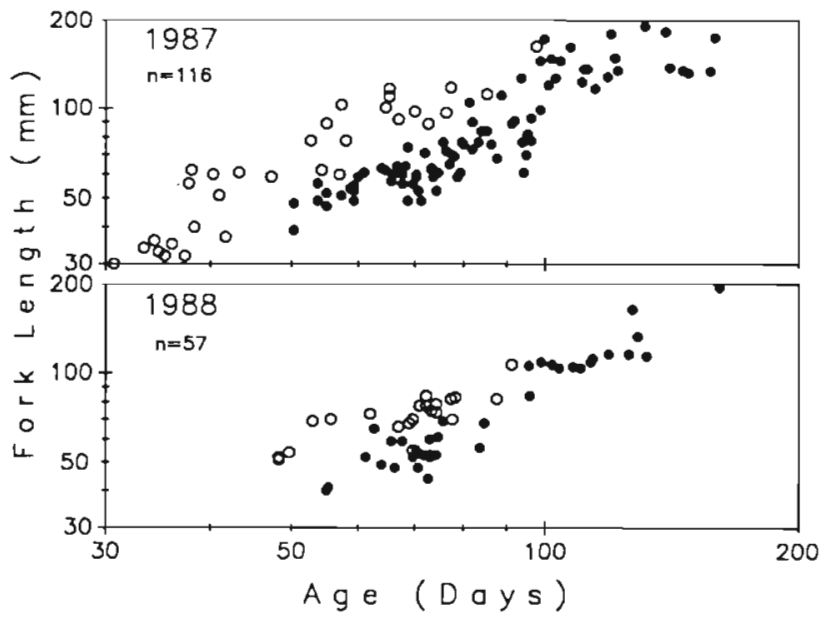

Fig. 5. Pomatomus saltatrix. Log-log plot of bluefish fork length (FL) on age. Least square regression equations for each cohort and year were: Spring-spawned fish $(\bullet), \log \mathrm{FL}=$ $-0.615+1.31(\log$ Age) in 1987 and $\log F L=-0.908+1.44$ ( $\log A g e)$ in 1988; summer-spawned fish (0), $\log F L=-0.596$ $+1.41(\log \mathrm{Age})$ in 1987 and $\log \mathrm{FL}=0.398+0.795(\log \mathrm{Age})$ in 1988. Coefficients of determination $\left(\mathrm{r}^{2}\right)$ ranged from 0.66 to 0.90 and were all significantly different from zero $(p<0.01)$

Table 3. Pomatomus saltatrix. Average oceanic growth rate $\left(\mathrm{mm} \mathrm{d}^{-1} \pm 95 \%\right.$ confidence limits; sample sizes in parentheses) estimated from bluefish captured at date of initial estuarine recruitment. Summer-spawned bluefish grew significantly faster than spring-spawned bluefish collected in all comparisons within the same sample location and year (Student's $t$-test; $\mathrm{p}<0.5$ )

\begin{tabular}{|c|c|c|c|c|}
\hline Sample location, year & Sample date & Spring-spawned & Sample date & Summer-spawned \\
\hline New York, 1987 & 15 Jun & $0.85 \pm 0.042(19)$ & 12 Aug & $0.91 \pm 0.062(6)^{\mathrm{a}}$ \\
\hline New Jersey, 1987 & $17-18$ Jun & $0.80 \pm 0.066(12)$ & $12-13 \mathrm{Aug}$ & $1.19 \pm 0.17$ \\
\hline New York, $1988^{\circ}$ & 13 Jun & $0.71 \pm 0.052(6)$ & 25 Aug & $1.08 \pm 0.076(9)$ \\
\hline
\end{tabular}

Table 4. Pomatomus saltatrix. Estuarine growth rates $\left(\mathrm{mm} \mathrm{d} \mathrm{d}^{-1} \pm 95 \%\right.$ confidence limits) as determined from the slope of least square regressions of fish length on capture date. All slopes and coefficients of determination were significantly different from zero $(p<0.001)$. nd: no data

\begin{tabular}{|lccc|}
\hline Location & Year & Spring-spawned & Summer-spawned \\
\hline Great South Bay & 1987 & $1.17 \pm 0.079\left(\mathrm{r}^{2}=0.85\right)$ & $\mathrm{nd}$ \\
New Jersey & 1987 & $1.31 \pm 0.079\left(\mathrm{r}^{2}=0.89\right)$ & $1.47 \pm 0.16\left(\mathrm{r}^{2}=0.71\right)$ \\
Great South Bay & 1988 & $1.21 \pm 0.099\left(\mathrm{r}^{2}=0.69\right)$ & $0.57 \pm 0.18\left(\mathrm{r}^{2}=0.26\right)$ \\
New Jersey & 1988 & $1.35 \pm 0.33 \quad\left(\mathrm{r}^{2}=0.64\right)$ & $1.36 \pm 0.38\left(\mathrm{r}^{2}=0.20\right)$ \\
a Summer-spawned bluefish were only collected on 1 date in Great South Bay during 1987 & \\
\end{tabular}




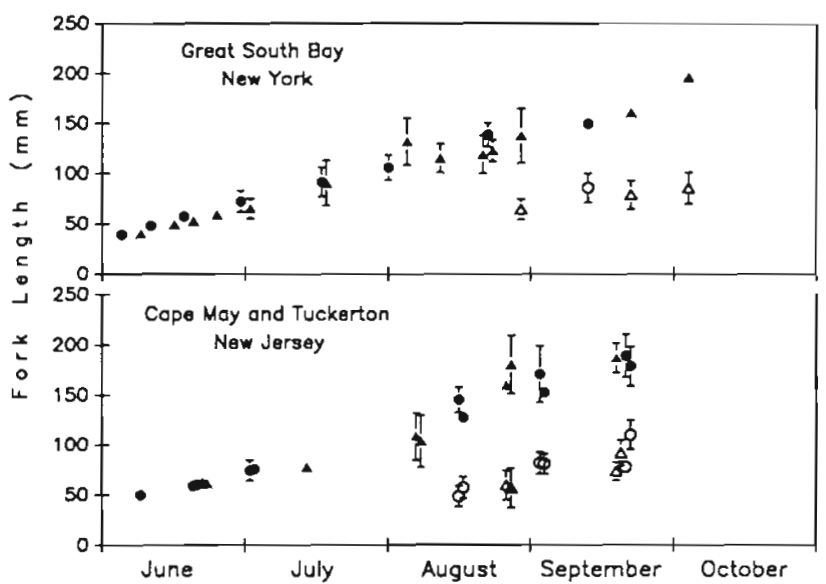

Fig. 6. Pomatomus saltatrix. Mean length \pm I SD of bluefish versus date of capture in Great South Bay and New Jersey samples. Means from spring-spawned bluefish (filled symbols) and summer-spawned fish (open symbols) are shown for both $1987(\bullet$ o) and $1988(\Lambda, \triangle)$

sample dates) over which the growth of summerspawned fish can be averaged before the onset of winter migration. By the time their first winter migration begins, the older, spring-spawned bluefish are about twice the size of summer-spawned bluefish.

\section{DISCUSSION}

\section{Bimodal spawning and recruitment to the New York Bight}

Our study confirms that the reproductive tactics of bluefish in the western North Atlantic involve multiple but distinct periods of spawning over the continental shelf followed by distinct episodes of juvenile recruitment to inshore waters of the New York Bight. The 2 recruitment episodes were clearly identified by lengthfrequency analyses, and otolith analyses showed that these 2 size classes of fish had birthdates falling within time intervals of either March to early May or mid-June to late July. These time periods closely correspond with peaks in abundance of larvae in the South Atlantic Bight and Middle Atlantic Bight, respectively (Norcross et al. 1974, Kendall \& Walford 1979, Collins \& Stender 1987).

Summer-spawned bluefish do contribute, at least in some years, to recruitment of bluefish in the New York Bight. Trends in CPUE of spring- and summerspawned fish in Great South Bay over a 4 yr period, encompassing both Nyman \& Conover's (1988) study and ours, demonstrate that in 1985 and 1986 springspawned fish were abundant and summer-spawned fish were absent (Fig. 7). In contrast, 1987 and 1988 were years when spring-spawned fish were less abun- dant and summer-spawned fish were present. Differences between the 2 pairs of years are not likely to be sampling artifacts because the seining gear and technique, and the stations sampled, were standardized across studies.

Our findings do not support the hypothesis that summer-spawned offspring are transported primarily to the western shore of the New York Bight. Summer-spawned bluefish were captured in all areas sampled including Long Island. This should not be, however, interpreted as evidence that circulation patterns in the New York Bight are unimportant to the dispersal and recruitment of YOY bluefish. Advection has, for example, been identified frequently as a major source of recruitment variability in marine fishes (Walford 1938, Cowen 1985, Sinclair \& Iles 1985, Wellington \& Victor 1988, Sale \& Steel 1989). Our results do suggest that average patterns of flow in the New York Bight may not predict the pattern of geographic variation in recruitment to the shoreline. Specific meterological or oceanographic events that coincide with the summer spawning season may be more important in any given year.

Bumpus (1969), for example, showed that temporary reversals in the normal southwesterly flow of the Middle Atlantic Bight waters can occur from April to September in years when low runoff from the Hudson and Delaware Rivers is coupled with strong southern winds. In 1988, the intensity and duration of southwest winds was unusually high in the New York Bight region (Swanson \& Zimmer 1990) and this was the year with the highest CPUE of summer-spawned bluefish in Great South Bay over the period from 1985 to 1988 (Fig. 7).

Alternatively, the abundance of spring-spawned bluefish could negatively affect the abundance of the summer-spawned cohort through cannibalism. YOY bluefish within estuaries are piscivorous (Grant 1962, Smale \& Kok 1983, Smale 1984, Friedland et al. 1988) and spring-spawned YOY fish are more than twice the average size of summer-spawned YOY fish during August and September. The near absence of summerspawned fish in years when spring-spawned fish are abundant (Fig. 7) is consistent with this hypothesis.

Based on the size range and date of capture of YOY fish in other studies in the New York Bight, the recruitment of spring-spawned bluefish appears to be generally more consistent than that of the summer cohort (Table 5). Vouglitois (1983), for example, found multimodal length distributions during August or September in some, but not all, years of a 5 yr study Estuaries to the east of Long Island appear to contain only springspawned bluefish. In Mount Hope Bay, Rhode Island, length-frequency distributions of YOY bluefish collected each year during 1985 to 1988 were consistently unimodal and sizes of these fish corresponded with the expected size of spring-spawned fish (Michael Sherer, 
Marine Research Inc., Falmouth, Massachusetts, unpubl.). Sampling throughout Narragansett Bay in 1986 and 1987 also suggested the presence of only spring-spawned bluefish (J,C. Powell, Rhode Island Division of Fish and Wildlife, West Kingston, Rhode Island, unpubl.).

\section{Oceanic and estuarine growth}

Oceanic growth rates were significantly higher for summer-spawned than for spring-spawned YOY bluefish. In addition, at least in 1987, summer-spawned fish recruited at a smaller size and earlier age than springspawned fish. Hence, summer-spawned bluefish do grow fast enough to reach a size permitting inshore migration before the onset of winter.

These results suggest that the oceanic environment experienced by summer-spawned fish is more suitable for growth, or that fish from the 2 spawning seasons differ genetically in growth rate (or both). Conover (1990) pointed out that growth rate of YOY fish averaged over the length of the growing season increases with latitude in a wide variety of species and that these differences are likely to have a genetic basis. However, in the case of bluefish, genetic differences between the spring-spawned (low latitude) and summer-spawned (high latitude) bluefish appear unlikely. Chiarella \& Conover (1990) classified adult bluefish as spring- or summer-spawned based on their back-calculated size at age 1 and showed that spring-spawned adults were

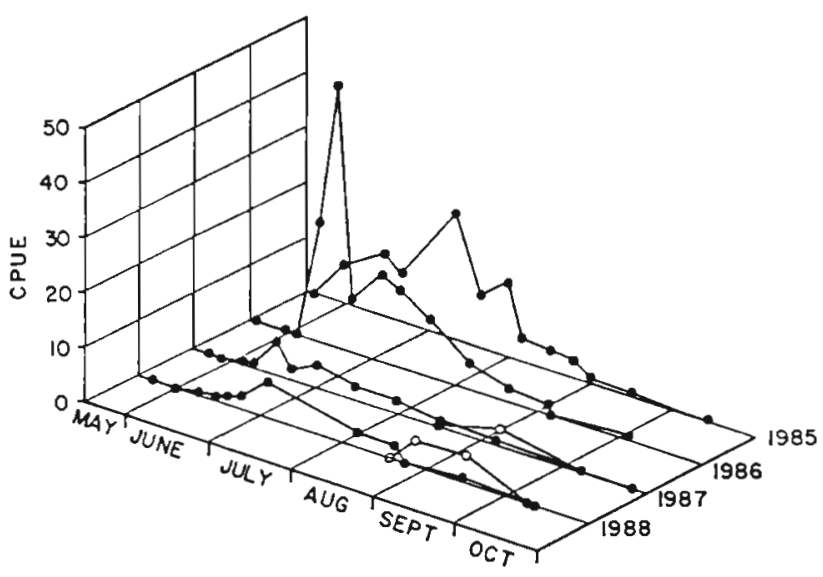

Fig. 7. Pomatomus saltatrix. Relative abundance (CPUE) of (•) spring-and (o) summer-spawned young-of-the-year bluefish in Great South Bay from 1985 to 1988. Data for 1985 and 1986 are from Nyman \& Conover (1988)

reproductively active during the summer spawning season. Moreover, electrophoretic data provide no strong evidence of genetic differentiation among the spring and summer cohorts (T. Present, A. Powell and $D$. Conover unpubl.). Hence, the 2 spawning seasons do not appear to be a source of reproductive isolation.

Temperatures experienced during the larval period may be responsible for differences in growth of the cohorts. Although temperatures during the spring spawning season in the South Atlantic Bight (18 to $26^{\circ} \mathrm{C}$ ) are similar to those occurring during summer spawning in the Middle Atlantic Bight (Kendall \& Wal-

Table 5. Pomatomus saltatrix. Presumptive recruitment of spring-and summer-spawned young-of-the-year bluefish to estuaries of the New York Bight based on length-frequency distributions or size ranges reported in various studies. All the above studies began at least by June and sampled through September, except for those marked with ('), which began in July. Sources: (1) Greeley 1939, (2) Briggs \& O'Connor 1971, (3) McClaine 1971, (4) Wilk et al. 1975, (5) Vouglitois 1983, (6) Friedland et al. 1988, (7) Nyman \& Conover 1988, (8) Young et al. 1988

\begin{tabular}{|c|c|c|c|}
\hline Year & $\begin{array}{l}\text { Spring-spawned } \\
\text { recruitment }\end{array}$ & $\begin{array}{l}\text { Summer-spawned } \\
\text { recruitment }\end{array}$ & Location; source \\
\hline 1938 & Pre-July & August & Long Island, $\mathrm{NY}_{i} 1^{\bullet}$ \\
\hline 1967 & Pre-July & None & Great South Bay, NY; $2^{*}$ \\
\hline 1968 & Pre-July & None & Great South Bay, NY; $2^{\circ}$ \\
\hline 1969 & June & None & Great Bay, $N J_{i} 3$ \\
\hline 1974 & June & September & New York Bight; 4 \\
\hline 1976 & May & August & Barnegat Bay, $\mathrm{NJ} ; 5$ \\
\hline 1977 & June & August & Barnegat Bay, NJ; 5 \\
\hline 1978 & June & None & Barnegat Bay, NJ; 5 \\
\hline 1979 & June & None & Barnegat Bay, NJ; 5 \\
\hline 1980 & June & September & Barnegat Bay, NJ; 5 \\
\hline 1981 & June & September & Sandy Hook, NJ; 6 \\
\hline 1983 & June & September & Sandy Hook, NJ; 6 \\
\hline 1984 & June & None & Sandy Hook, NJ; 6 \\
\hline 1985 & May & None & Great South Bay, NY; 7 \\
\hline 1986 & June & None & Great South Bay, NY; 7 \\
\hline 1986 & June & None & Jamaica Bay, NY; 7,8 \\
\hline 1986 & Pre-July & September & Hudson River, NY; $7,8^{\circ}$ \\
\hline
\end{tabular}


ford 1979), larvae from the spring spawning season are likely to encounter lower temperatures as they are transported northward. Shima (1990) collected many larval bluefish downstream from the main spring spawning area (north of Cape Hatteras) at temperatures less than $18^{\circ} \mathrm{C}$. Spring-spawned juveniles were later captured near the edge of the continental shelf off the New York Bight at 12 to $18^{\circ} \mathrm{C}$ (Shima 1990). Summer-spawned bluefish in the New York Bight, on the other hand, are not transported northward and presumably do not encounter temperatures below those that occur at spawning. The lower temperatures experienced by northward drifting spring-spawned fish may be responsible for their slower growth rate and longer duration of the oceanic larval phase.

Growth rate of spring-spawned fish increased significantly after recruitment to inshore waters, from about $0.8 \mathrm{~mm} \mathrm{~d}^{-1}$ in the ocean to about $1.25 \mathrm{~mm} \mathrm{~d}{ }^{1}$ in the estuary (Tables $3 \& 4$ ). Similarly high rates of growth for YOY bluefish within estuaries have been found in other studies. Nyman \& Conover (1988) reported a mean growth rate of $1.3 \mathrm{~mm} \mathrm{~d}^{-1}$ for spring-spawned bluefish from Great South Bay. Estuarine growth rates for spring-spawned YOY bluefish from Mount Hope Bay, Rhode Island, varied from 0.9 to $2.1 \mathrm{~mm} \mathrm{~d}^{-1}$ among years from 1985 to 1988 (mean $=1.5 \mathrm{~mm} \mathrm{~d}^{-1}$; Michael Sherer unpubl.). Estuarine growth of summer-spawned YOY bluefish was more difficult to assess because they occupied inshore waters for little more than a month and our results were highly variable between years.

\section{Implications of bimodal spawning and recruitment}

We have demonstrated that the spatial and temporal dynamics of spawning in bluefish along the US East Coast result in an intra-annual pattern of bimodal recruitment to estuaries of the New York Bight. This spawning and recruitment pattern is unlike that of most other temperate marine fish stocks that generally spawn once a year, and that do so presumably because environmental constraints limit spawning to a particular place and time when conditions are optimal for survival of offspring (Sherman et al. 1984, Bye 1990). Where environmental conditions permit, multimodal spawning would appear to have several plausible advantages, including increased total annual fecundity (Burt et al. 1988) and bet-hedging on the probability of offspring survival (Stearns 1976). In bluefish, bimodal spawning is accomplished by spawning at distinct times and locations where different advective forces ensure recruitment to estuarine nurseries: i.e. in early spring near the edge of a northerly flowing warm water mass (the Gulf Stream) and in summer over the midshelf directly offshore from estuaries.
By virtue of earlier spawn dates and rapid growth after invasion of northern estuaries, spring-spawned fish are more than twice the length of summerspawned fish at the onset of fall migration. This size differential may have important consequences for relative fitness of fish from the 2 cohorts. Winter survival of YOY fish is known to be size-dependent in a number of fish species and it is often larger individuals that survive more readily (Conover 1990). Perhaps sizedependent winter survival explains why Chiarella \& Conover (1990) found that the 1981 to 1984 year classes of adult bluefish in the New York Bight appear to consist almost entirely of spring-spawned fish. On the other hand, Lassiter (1962) presented evidence that the spring-and summer-spawned adults were more equal in abundance during the 1960s. The factors that contribute to successful recruitment of spring- and summer-spawned bluefish, and how these combine to determine year-class strength, are worthy of further investigation.

The general features of spawning and recruitment in bluefish of the western North Atlantic appear to be repeated in other parts of the world. Intra-annual bimodal spawning has been reported in bluefish off the coast of Senegal (Champagnat 1983). Off the southeastern coast of Africa, bluefish larvae are transported in the Agulhas Current to southern estuaries but it is not clear if there is more than 1 spawning season (van der Elst 1976, Smale 1984). Bluefish also appear to spawn upstream from potential recruitment sites in the East Australian Current (Pollock 1984), and migration of young bluefish from offshore to inshore waters has been reported in the Black Sea (Oben 1957). Research on the spawning and recruitment of bluefish in these regions would allow comparisons of reproductive tactics in different oceanic environments.

Acknowledgements. We thank Louis Chiarella and Francis Juanes for assistance in field collections and Robert Cerrato and Robert Cowen for reviewing an earlier draft of this manuscript. Susan Kaiser made helpful comments on a later revision. Byron Young and Kim McKown contributed valuable data and samples from the Hudson River and western Long Island. Kenneth Able helped provide logistical support for sampling in New Jersey. Suffolk County and US Fish and Wildlife Service provided permits to access certain sampling stations. We thank Michael Sherer and Christopher Powell for making unpublished data available to us. An earler version of this paper was submitted by R.S.M. to the Graduate School of the State University of New York at Stony Brook in partial fulfillment of the requirements of an M.Sc degree in Marine Environmental Sciences. Funding was provided by grants to D.O.C. from the NY-DEC and from the Office of Sea Grant. National Oceanic and Atmospheric Administration, under grant NA86AA-D-SG045 to the New York Sea Grant Institute. This paper is contribution no. 837 of the Marine Sciences Research Center, State University of New York at Stony Brook. 


\section{LITERATURE CITED}

Bigelow, H. B., Schroeder, W. C. (1953). Fishes of the Gulf of Maine. Fish. Bull. U.S. 53: 383-389

Briggs, J. C. (1960). Fishes of worldwide (circumtropical) distribution. Copeia 1960: 171-180

Briggs, P. T., O'Connor, J. S. (1971). Comparison of shore-zone fishes over naturally vegetated and sand-filled bottoms in the Great South Bay. N.Y Fish Game J. 18(1): 15-41

Bumpus, D. F. (1969). Reversals in the surface drift in the Middle Atlantic Bight area. Deep Sea Res. 16 (suppl.): 17-23

Burt, A., Kramer, D. L. Nakatsuru, K., Spry, C. (1988). The tempo of reproduction in Hyphessobrycon pulchripinnin (Characidae), with a discussion on the biology of 'multiple spawning' in fishes. Environ. Biol. Fish. 22(1): 15-27

Bye, V. J. (1990). Temperate marine teleosts. In: Munro, A. D., Scott, A. P., Lam, T. J. (eds.) Reproductive seasonality in teleosts: environmental influences. CRC Press, Boca Raton, Florida, p. 125-143

Champagnat, C. (1983). Peche, biologie et dynamique du tassergal (Pomatomus saltator, Linnaeus, 1766) sur les cótes Senegalo-Mauritaniennes. Travaux et documents de L'Orstrom. No. 168, Paris

Chiarella, L. A., Conover, D. O. (1990). Spawning season and first-year growth of adult bluefish from the New York Bight. Trans. Am. Fish. Soc. 119: 455-462

Collins, M. R., Stender, B. W (1987). Larval king mackerel (Scomberomorus cavalla), Spanish mackerel (S. maculatus), and bluefish (Pomatomus saltatrix) off the southeast coast of the United States, 1973-1980. Bull. mar Sci. 41(3): 822-834

Conover, D. O. (1990). The relation between capacity for growth and length of growing season: evidence for and implications of countergradient variations. Trans. Am. Fish. Soc. 119: 416-430

Conover, W J., Iman, R. L. (1976). On some alternative procedures using ranks for the analysis of experimental designs. Communications in Statistics A5(14): 1349-1368

Cowen, R. K. (1985). Large scale pattern of recruitment by the labrid, Semicossyphus pulcher: causes and implications. J. mar Res. 43: 719-742

Friedland, K. D., Garman, G. C., Bejda, A. J., Studholme, A. L., Olla, B. (1988). Interannual variation in diet and condition in juvenile bluefish during estuarine residency. Trans. Am. Fish. Soc. 117: $474-479$

Grant, G. C. (1962). Predation of bluefish on young Atlantic menhaden in Indian River, Delaware. Chesapeake Sci. 3: $45-46$

Greeley, J. R. (1939). A biological survey of the salt waters of Long Island, 1938, Part II, Fishes and habitat conditions of the shore zone based upon July and August seining investigations. State of New York Conservation Department Rep. No. XV, Albany, NY, p. 72-91

Kendall, A. W. Jr, Walford, L. A. (1979). Sources and distribution of bluefish, Pomatomus saltatrix, larvae and juveniles off the East Coast of the United States. Fish. Bull. U.S $77(1): 213-227$

Lassiter, R. R. (1962). Life history aspects of the bluefish Pomatomus saltatrix (Linnaeus), from the coast of North Carolina. M.Sc. thesis, North Carolina State College, Raleigh

Lenanton, R. C. J., Potter, I. C. (1987). Contribution of estuaries to commercial fisheries in temperate western Australia and the concept of estuarine dependence. Estuaries 10(1): 28-35

McBride, R. S. (1989). Comparative growth and abundance of spring-versus summer-spawned young-of-year bluefish,
Pomatomus saltatrix, recruiting to the New York Bight M.Sc. thesis, State University of New York, Stony Brook

McClaine, J. F. (1971). Inventory of major estuarine systems in New Jersey. COM-73-11106, NJ Department of Environmental Protection, Trenton, NJ, p. 29

Norcross, J. J., Richardson, S. L., Massmann, W. H., Joseph, E. B. (1974). Development of young bluefish (Pomatomus saltatrix) and distribution of eggs and young in Virginian coastal waters. Trans. Am. Fish. Soc. 103(3): 477-497

Nyman, R. M., Conover, D. O. (1988). The relation between spawning season and the recruitment of young-of-the-year bluefish, Pomatomus saltatrix, to New York. Fish. Bull. U.S. $66(2): 237-250$

Oben, L. C. (1957). About the drifting approach of fingerling bluefish (Pomatomus saltatrix) (Linnaeus) to the shores of the Black Sea in the Karadaga region (1947-1954). Trudy Karadaga Biol. Stn. Acad. Sci. UKR (U.S.S.R.) 14: 155-157

Pollock, B. R. (1984). The tailor (Pomatomus saltatrix) fishery at Fraser Island and its relation to the life-history of the fish. Proc. R. Soc. Qd 95: 23-28

Powles, H. (1981). Distribution and movements of neustonic young of estuarine dependent (Mugil spp., Pomatomus saltatrix) and estuarine independent (Coryphaena spp.) fishes off the southeastern United States. Rapp. P.-v. Réun. Cons. int. Explor Mer 178: 207-209

Sale, P. F., Steel, W. J. (1989). Temporal variability in patterns of association among fish species on coral patch reefs. Mar. Ecol. Prog. Ser 51: 35-47

SAS Institute, Inc. (1988). SAS/STAT User's Guide: Release 6.03. SAS Institue, Inc., Cary, NC

Sherman, K., Snith, W., Morse, W., Berman, M., Gree, J., Ejsymont, L. (1984). Spawning strategies of fishes in relation to circulation, phytoplankton production, and pulses in zooplankton off the northeastern United States. Mar Ecol. Prog. Ser. 18: 1-19

Shima, M. (1990). Oceanic transport of the early life stages of bluefish (Pomatomus saltatrix) from Cape Hatteras to the Mid-Atlantic bight. M.Sc. thesis, State University of New York, Stony Brook

Sinclair, M. Iles, T D. (1985). Atlantic herring (Clupea harengus) distributions in the Gulf of Maine-Scotian Shelf area in relation to oceanographic features. Can. J. Fish. Aquat. Sci. $42(5): 880-887$

Smale, M. J. (1984). Inshore small-mesh trawling survey of the Cape south coast, Part 3. The occurrence and feeding of Argyrosomus hololepidotus, Pomatomus saltatrix and Merluccius capensis. S. Afr. J. Zool. 19: 170-179

Smale, M. J., Kok, H. M. (1983). The occurrence and feeding of Pomatomus saltatrix (elf) and Lichia amia (leervis) juveniles in two Cape south coast estuaries. S. Afr. J. Zool 18: $337-342$

Stearns, S. C. (1976). Life history tactics: a review of the ideas. Q. Rev. Biol. 51. 3-47

Swanson, R. L., Zimmer, R. L. (1990). Meteorological conditions leading to the 1987 and 1988 washups of floatable wastes on New York and New Jersey beaches and comparison of these conditions with the historical record Estuar. coast. Shelf Sci. 30: 59-78

US Dept of Commerce (1988). Status of the fishery resources off the northeastern United States for 1988. NOAA Technical Memorandum NMFS-F/NEC-63. U.S. Dept of Commerce, Washington, D.C.

van der Elst, R. (1976). Game fish of the east coast of southern Africa. I. The biology of the elf, Pomatomus saltatrix (Linnaeus), in the coastal waters of Natal. Invest. Rep. no. 44 oceanogr. Res. Inst., Durban, Republic of South Africa, p. $1-59$ 
Vouglitois, J. J. (1983). The ichthyofauna of Barnegat Bay. New Jersey - relationships between long term temperature fluctuations and the population dynamics and life history of temperate estuarine fishes during a five year period, 1976-1980. M.Sc. thesis, Rutgers University, New Brunswick

Walford, L. A. (1938). Effects of currents on distribution and survival of the eggs and larvae of haddock (Melanogrammus aeglefinus) on Georges Bank. Fish. Bull. U.S. 49: 1-73

Wellington, G. M., Victor, B. C. (1988). Variation in components of reproductive success in an undersaturated

This article was presented by K.L. Heck, Jr, Dauphin Island, Alabama, USA population coral-reef damselfish: a field perspective. Am. Nat. 131(4): 588-601

Wilk, S. J., Morse, W W., Ralph, D. E., Steady, J. (1975). Life history aspects of New York Bight finfishes (June 1974-June 1975). Annual Report, U.S. Department of Commerce. NOAA, NMFS, Sandy Hook Laboratory, Highlands, NJ

Young, B. H., McKown, K. A., Vecchio, V. J. (1988). A study of the striped bass in the marine district of New York. V. Rep. to the US Dept of Commerce (NOAA/NMFS). AFC-13-3. New York Dept of Environmental Conservation, Stony Brook, NY

Manuscript first received: December 3, 1990

Revised version accepted: October 28, 1991 